\title{
Remote ischaemic preconditioning of the heart: remote questions, remote importance, or remote preconditions?
}

\author{
Jürgen Peters
}

Received: 23 April 2011 / Accepted: 26 April 2011/Published online: 5 May 2011

(C) Springer-Verlag 2011

Keywords Anaesthetics · Cardiac surgery ·

Coronary artery disease $\cdot$ Ischaemic preconditioning

Options and clinical solutions to decrease damage to the heart in ischaemia/reperfusion settings such as recent myocardial infarction, unstable angina, coronary artery interventions, and cardiac surgery have long been a holy grail for physiologists, cardiologists, cardiac surgeons, and anaesthetists alike. Specifically, the concepts of somehow "conditioning" a heart to attenuate ischaemia/reperfusionrelated injury or even to expand the magnitude of tolerable injury have evolved over the last decades from attenuation of (secondary) injury evoked by reperfusion, over ischaemic preconditioning (and postconditioning) and anaesthetic preconditioning, to remote ischaemic preconditioning (RIPC), as attested by a myriad of papers, editorials, grants, and symposia.

While ischaemic preconditioning (IPC) of the heart has proved impressively successful to decrease infarct size in the area at risk in otherwise healthy mice, rats, dogs, pigs, clinical results were mixed and remained controversial. Furthermore, IPC of the heart is difficult to apply in clinical settings. Although many hypotheses were raised to explain why IPC did not catch on in real patients, the bottomline is that IPC has not achieved a major role in clinical practice. IPC has been "lost in translation", as one review candidly put it [23]. Similarly, with respect to anaesthetic preconditioning, it has clearly been shown that volatile anaesthetics

\section{J. Peters $(\square)$}

Klinik für Anästhesiologie und Intensivmedizin,

Universität Duisburg-Essen, Universitätsklinikum Essen,

Hufelandstr. 55, 4511 Essen, Germany

e-mail: juergen.peters@uni-duisburg-essen.de such as isoflurane and sevoflurane as well as opiates can decrease infarct size in animals and isolated hearts under some experimental conditions $[3,16,17,24,25,30,31$, $34,35]$. The intravenous anaesthetic propofol has also been reported to improve cardiac function in reperfused isolated hearts [20]. However, clinical studies failed to clearly show superiority of certain anaesthetic regimens in patients at cardiac risk. [1, 5, 7, 21, 22] Thus, many anaesthetists for cardiac patients simply employ those anaesthetics, i.e., volatile anaesthetics and opioids, that worked best in the lab to protect the heart.

This was the setting when the newest kid on the block, i.e., RIPC of the heart, got on stage. Episodes of ischaemia/ reperfusion of vascular territories remote from the heart, such as limbs, liver, or gut have been convincingly shown in many but not all studies, again mostly in the lab, to decrease myocardial injury or the extent of infarction in the area at risk [2, 6, 10, 18, 19, 27-29, 33, 36]. In fact, RIPC may even protect organs other than the heart such as kidney or brain. Although RIPC is around for some 15 years now and its basic mechanisms and related issues continue to be bull eyed in the lab [2, 6, 10, 12, 18, 19, 27-29, 33, 36] it attracted attention amongst clinicians only quite recently. Many specialties jumped on the bandwagon and investigated, for instance, even effects of RIPC on microvascular flaps. Since repetitive limb ischaemia can be implemented so easily, without apparent risks, and without additional costs almost every illness appears to be treatable anytime by RIPC. Psychologically, by offering transient remote organ ischaemia in exchange for a better fate regarding the core issues, i.e., heart and survival, RIPC almost resembles a sacrifice to the gods. Nevertheless, the gods may not have listened and clinical results obtained with RIPC remain confusing.

In this issue, Karuppasamy et al. [14] present another negative randomized clinical trial for RIPC when evoked 
by repetitive upper arm ischaemia in a rather small cohort of patients prior to coronary artery bypass surgery, as evidenced by similar troponin concentrations over time with and without RIPC. Furthermore, central venous concentrations of a panel of cytokines and growth factors were unaltered by RIPC. While the authors despite airing negative results should be applauded for their enthusiasm and sampling of clinical data, their methodology may also reveal why clinical results obtained with RIPC remain confusing. Specifically, their cohorts $(n=27$ in each group) included patients less than 85 years of age of three (genetic) ethnicities and these patients underwent either (cold blood or St. Thomas') cardioplegia or repetitive ascending aortic crossclamping with the heart in fibrillation. Furthermore, while patients receiving sulfonyl urea drugs were not enrolled approximately $20 \%$ of their patients suffered from diabetes mellitus. So yes, such menus derived from many recipes are served in operating rooms but can we conclude from such data that RIPC is clinically futile? Rather not. All these apparently remote preconditions for preconditioning create much heterogeneity, have been hypothesized to interfere with cardiac IPC [3, 9, 15, 26, 32], and hence might interfere with RIPC as well.

Of particular importance, despite the documented role of anaesthetics in mediating preconditioning on their own, anaesthetic regimens are hardly standardized in RIPC trials and respective information, if any, is often limited to a few words in the manuscripts " method sections. The present paper by Karuppasamy et al. [14] is no exception in using too many recipes for cooking a gourmet entre. These authors used propofol for induction, isoflurane and the opioid remifentanil for maintenance of anaesthesia only until initiation of cardiopulmonary bypass, but propofol infusion during bypass and hence upon cardiac reperfusion as well as for the remainder of surgery [14]. At the very least, this unnecessarily adds to the multitude of variables in their study and even raises the question whether different results may have been obtained if isoflurane/remifentanil had been continued throughout reperfusion and thereafter. Interestingly, in another negative study [29], investigators had used propofol/alfentanil anaesthesia before CPB but had switched to volatile anaesthetics (enflurane and sevoflurane) during bypass. On the other hand, Hausenloy et al. [8] reported a substantial decrease in troponin concentrations with RIPC in patients not receiving volatile anaesthetics before bypass but did not mention specifics on the anaesthetic regimen during bypass and hence reperfusion. From a more general perspective, it is presently unknown, even from any work in the lab, whether and to what extent RIPC and specific anaesthetics and/or their timing might interfere with one another. If similar downstream mechanisms are involved in RIPC and volatile anaesthetic preconditioning [11], it is conceivable that specific anaesthetics may either help or hinder RIPC. The bottomline is that clinical trials assessing the merits of RIPC must be simplified and stratified for the anaesthetics used, their timing in relation to RIPC, and the period thereafter including cardiac reperfusion. In fact, such apparently remote preconditions may turn out to be essential for remote preconditioning.

Besides remote preconditions there may be other caveats as well for RIPC to successfully catch on in real patients. As outlined above, all forms of conditioning the heart rest on the demonstration in the lab that conditioning attenuates myocardial infarction in the area at risk. Luckily, however, this is not the setting in the operating room and in CABG patients in particular. Although there are occasional patients where CABG surgery turns into disaster and large infarction ensues it is fair to say that most surgeries in good hands go rather uneventful, graft malfunction, if present, is recognized and fixed immediately, and most hearts just need some inotropic support for some hours to eventually make an uneventful recovery. Ironically then, RIPC is investigated mostly under conditions where it may not exert clinically discernable, relevant effects. The better the surgeons the more likely it is that RIPC studies turn out negative results (even in academic centres). Thus, it might reflect poor scientific wisdom and a rather remote question to ask for effects of RIPC in cohorts of average cardiac surgical patients.

By the same token, due to the lucky absence of frequent large myocardial infarctions in clinical practice secondary to cardiac interventions or surgery, clinical investigators have turned to surrogate endpoints like serial troponin concentrations to assess effects of RIPC. Although troponin concentrations are linked to cardiac outcome in general $[4,13]$ it is questionable whether this represents an appropriate endpoint of clinical importance. Even studies showing, albeit in small cohorts, decreased troponin release with RIPC did not reveal an impact of RIPC on survival $[8,33]$. Thus, RIPC might turn out to have remote importance as well.

In summary, the jury is still out on RIPC. At present, it appears that we rather deal with remote preconditions, remote questions, and, possibly, also with remote importance. Nevertheless, until the jury comes in announce its verdict, its still heart play.

\section{References}

1. Belhomme D, Peynet J, Louzy M, Launay JM, Kitakaze M, Menasche P (1999) Evidence for preconditioning by isoflurane in coronary artery bypass graft surgery. Circulation 100:340-344

2. Birnbaum Y, Hale SL, Kloner RA (1997) Ischemia preconditioning at a distance. Reduction of myocardial infarct size by partial 
reduction of blood supply combined with rapid stimulation of the gastrocnemius muscle in the rabbit. Circulation 96:1641-1646

3. Boengler K, Schulz R, Heusch G (2009) Loss of cardioprotection with ageing. Cardiovasc Res 83:247-261. doi:10.1093/cvr/cvp033

4. Croal BL, Hillis GS, Gibson PH, Fazal MT, El-Shafei H, Gibson G, Jeffrey RR, Buchan KG, West D, Cuthbertson BH (2006) Relationship between postoperative cardiac troponin I levels and outcome of cardiac surgery. Circulation 114:1468-1475. doi: 10.1161/CIRCULATIONAHA.105.602370

5. De Hert SG, Van der Linden PJ, Cromheecke S (2004) Choice of primary anesthetic regimen can influence intensive care unit length of stay after coronary surgery with cardiopulmonary bypass. Anesthesiology 101:9-20

6. Gho BC, Schoemaker RG, van den Doel MA, Duncker DJ, Verdouw PD (1996) Myocardial protection by brief ischemia in noncardiac tissue. Circulation 94:2193-2200

7. Haroun-Bizri S, Khoury SS, Chehab IR, Kassas CM, Baraka A (2001) Does isoflurane optimize myocardial protection during cardiopulmonary bypass? J Cardiothorac Vasc Anesth 15:418421. doi:10.1053/jcan.2001.24954

8. Hausenloy DJ, Mwamure PK, Venugopal V, Harris J, Barnard M, Grundy E, Ashley E, Vichare S, Di Salvo C, Kolvekar S, Hayward M, Keogh B, MacAllister RJ, Yellon D (2007) Effect of remote ischemic preconditioning on myocardial injury in patients undergoing coronary artery bypass graft surgery: a randomised controlled trial. Lancet 370:575-579. doi:10.1016/S0140-6736 (07)61296-3

9. Hausenloy DJ, Baxter G, Bell R, Bøtker HE, Davidson SM, Downey J, Heusch G, Kitakaze M, Lecour S, Mentzer R, Mocanu MM, Ovize M, Schulz R, Shannon R, Walker M, Walkinshaw G, Yellon DM (2010) Translating novel strategies for cardioprotection: the Hatter Workshop Recommendations. Basic Res Cardiol 105:677-686. doi:10.1007/s00395-010-0121-4

10. Heusch G, Schulz R (2002) Remote preconditioning. J Moll Cell Cardiol 34:1279-1281. doi:10.1006/jmcc.2002.2093

11. Heusch G, Boengler K, Schulz R (2008) Cardioprotection-nitric oxide, protein kinases, and mitochondria. Circulation 118:19151919 doi:10.1161/CIRCULATIONAHA.108.805242

12. Heusch G, Kleinbongard P, Böse D, Levkau B, Hause M, Schulz R, Erbel R (2009) Coronary microembolization: from bedside to bench and back to bedside. Circulation 120:1822-1836. doi: 10.1161/CIRCULATIONAHA.109.888784

13. Higgins JPH, Higgins JA (2003) Elevation of cardiac troponin I indicates more than myocardial ischemia. Clin Invest Med 26:133-147

14. Karuppasamy P, Chaubey S, Dew T, Musto R, Sherwood R, Desai J, John L, Shah A, Marber M, Kunst G (2011) Remote intermittent ischemia before coronary arery bypass graft surgery-a strategy to reduce injury and inflammation? Basic Res Cardiol (in press)

15. Kehl F, Krolikowski JG, Mraovic B, Pagel PS, Warltier DC, Kersten JR (2002) Hyperglycaemia prevents isoflurane-induced preconditioning against myocardial infarction. Anesthesiology 96:183-188

16. Kersten JR, Orth KG, Pagel PS (1997) Role of adenosine in isoflurane-induced cardioprotection. Anesthesiology 86:1128-1139

17. Kersten JR, Schmeling TJ, Hettrick DA (1996) Mechanisms of myocardial protection by isoflurane: role of adenosine triphosphate-regulated potassium (KATP) channels. Anesthesiology 85:794-807

18. Kharbandra RK, Li J, Konstantinov IE (2006) Remote ischaemic preconditioning protects against cardiopulmonary bypass-induced tissue injury: a preclinical study. Heart 92:1506-1511. doi: 10.1136/hrt.2004.042366

19. Kharbanda RK, Mortensen UM, White PA, Kristiansen SB, Schmidt MR, Hoschtitzky JA, Vogel M, Sorensen K, Redington
AN, MacAllister R (2002) Transient limb ischemia induces remote ischemic preconditioning in vivo. Circulation 106:28812883. doi:10.1161/01.CIR.0000043806.51912.9B

20. Kokita N, Hara A, Abiko Y, Arakawa J, Hashizume H, Namiki A (1998) Propofol improves functional and metabolic recovery in ischemic reperfused isolated rat hearts. Anesth Analg 86:252-258

21. Landoni G, Fochi O, Torri G (2008) Cardiac protection by volatile anaesthetics: a review. Curr Vasc Pharmacol 6:108-111

22. Lee MC, Chen CH, Kuo MC, Kang PL, Lo A, Liu K (2006) Isoflurane preconditioning-induced cardio-protection in patients undergoing coronary artery bypass grafting. Eur J Anaesthesiol 23:841-847. AID-doi:10.1017/S0265021506000354

23. Ludman AJ, Yellon DM, Hausenloy DJ (2010) Cardiac preconditioning for ischaemia: lost in translation. Dis Model Mech 3:35-38. doi:10.1242/dmm.003855

24. Mullenheim J, Ebel D, Frassdorf J, Preckel B, Thamer V, Schlack W (2002) Isoflurane preconditions myocardium against infarction via release of free radicals. Anesthesiology 96:934-940

25. Piriou V, Chiari P, Knezynski S, Bastien O, Loufoua J, Lehot JJ, Foëx P, Annat G, Ovize M (2000) Prevention of isofluraneinduced preconditioning by 5-hydroxydecanoate and gadolinium. Anesthesiology 93:756-764

26. Pantos C, Mourouzis I, Cokkinos DV (2007) Protection of the abnormal heart. Heart Fail Rev 12:319-330. doi:10.1007/s10741007-9036-z

27. Przyklenk K, Bauer B, Ovize M, Kloner RA, Whittaker P (1993) Regional ischemic "preconditioning" protects remote virgin myocardium from subsequent sustained coronary occlusion. Circulation 87:893-899

28. Przyklenk K, Darling CE, Dickson EW, Whittaker P (2003) Cardioprotection "outside the box". The evolving paradigm of remote preconditioning. Basic Res Cardiol 98:149-157. doi: 10.1007/s00395-003-0406-y

29. Rahman IA, Mascaro JG, Steeds RP, Frenneaux MP, Nightingale P, Gosling P, Townsend P, Townend JN, Green D, Bonser RS (2010) Remote ischemic preconditioning in human coronary artery bypass surgery-from promise to disappointment? Circulation 122 (suppl 1): S53-59. doi:10.1161/CIRCULATIONAHA.109.926667

30. Roscoe AK, Christensen JD, Lynch C (2000) Isoflurane, but not halothane, induces protection of human myocardium via adenosine A1 receptors and adenosine triphosphate-sensitive potassium channels. Anesthesiology 92:1692-1701

31. Schultz JE, Hsu AK, Gross GJ (1996) Morphine mimics the cardioprotective effect of ischemic preconditioning via a glibenclamide-sensitive mechanism in the rat heart. Circ Res 78:1100-1104

32. Tanaka K, Kehl F, Gu W (2002) Isoflurane-induced preconditioning is attenuated by diabetes. Am J Physiol Heart Circ Physiol 282:H2018-H2023. doi:10.1152/ajpheart.01130.2001

33. Thielmann M, Kottenberg E, Boengler K, Raffelsieper C, Neuhaeuser M, Peters J, Jakob H, Heusch G (2010) Remote ischemic preconditioning reduces myocardial injury after coronary artery bypass grafting with crystalloid cardioplegic arrest. Basic Res Cardiol 105:657-664. doi:10.1007/s00395-010-0104-5

34. Toller WG, Kersten JR, Hagel PS, Hettrick DA, Warltier DC (1999) Sevoflurane reduces myocardial infarct size and decreases time threshold for ischemic preconditioning in dogs. Anesthesiology 91:1437-1464

35. Tsuchida A, Liu Y, Liu GS, Cohen MV, Downey JM (1994) Alpha I-adrenergic agonists preconditioning rabbit ischemia myocardium independent of adenosine by direct activation of protein kinase C. Circ Res 75:576-585

36. Weinbrenner C, Schulze F, Sarvary L, Strasser RH (2004) Remote preconditioning by infrarenal aortic occlusion is operative via delta1-opioid receptors and free radicals in vivo in the rat heart. Cardiovasc Res 61:591-599. doi:10.1016/j.cardiores. 2003.10.008 